\title{
A New Hydrogenated Azaphilone Sch 725680 from Aspergillus sp.
}

\author{
Shu-Wei Yang, Tze-Ming Chan, Joseph Terracciano, Reena Patel, Mahesh Patel, \\ Vincent Gullo, Min Chu
}

Received: September 28, 2006 / Accepted: October 16, 2006

(C) Japan Antibiotics Research Association

Abstract A new hydrogenated azaphilone Sch725680 (1) was isolated and identified from the culture of an Aspergillus sp. The structure elucidation of $\mathbf{1}$ was achieved based on extensive NMR spectroscopic analyses. Compound $\mathbf{1}$ showed inhibitory activity against Saccharomyces cerevisiae (PM503) and Candida albicans (C43) with MICs of 8 and $64 \mu \mathrm{g} / \mathrm{ml}$, respectively.

Keywords azaphilone, antifungal, antimicrobial, structure elucidation

A number of azaphilones and hydrogenated azaphilones have been isolated from various microorganisms, mainly fungal species, such as Emericella falconensis [1 3], Penicillium multicolor [4], Penicillium funiculosum [5], and Penicillium sclerotiorum [6]. Many of them have been described to exhibit inhibitory activities against various therapeutic targets, such as inhibition of acyl-CoA: cholesterol acyltransferase [4], cholesteryl ester transfer protein [7], platelet-derived growth factor [8], endothelin receptor [6], gp120-CD4 [9], monoamine oxidase [10], and phospholipase $\mathrm{A}_{2}$ [11]. Some azaphilones have also been reported to display inhibitory activity of tumor promotion [12].

In the course of our continuing search for novel

S.-W. Yang (Corresponding author), T.-M. Chan, J. Terracciano, R. Patel, M. Patel, V. Gullo, M. Chu: ScheringPlough Research Institute, 2015 Galloping Hill Road, Kenilworth, NJ 07033, USA, E-mail: shu-wei.yang@spcorp.com

Present address: M. Chu, J. Terracciano: Cubist Pharmaceuticals, Inc. 65 Hayden Ave. Lexington, MA 02421, USA antimicrobial agents $[13,14]$, we have isolated and identified a novel hydrogenated azaphilone Sch 725680 (1), from an Aspergillus sp. culture (SPRI-0814). In this paper, we report the fermentation, isolation, structure elucidation and antimicrobial activity of $\mathbf{1}$ (Fig. 1).

Fermentation studies of Aspergillus sp. culture SPRI0814 were conducted in shake flasks. Stock cultures were maintained as frozen whole broths at $-80^{\circ} \mathrm{C}$ in a final concentration of $10 \%$ glycerol. The germination medium

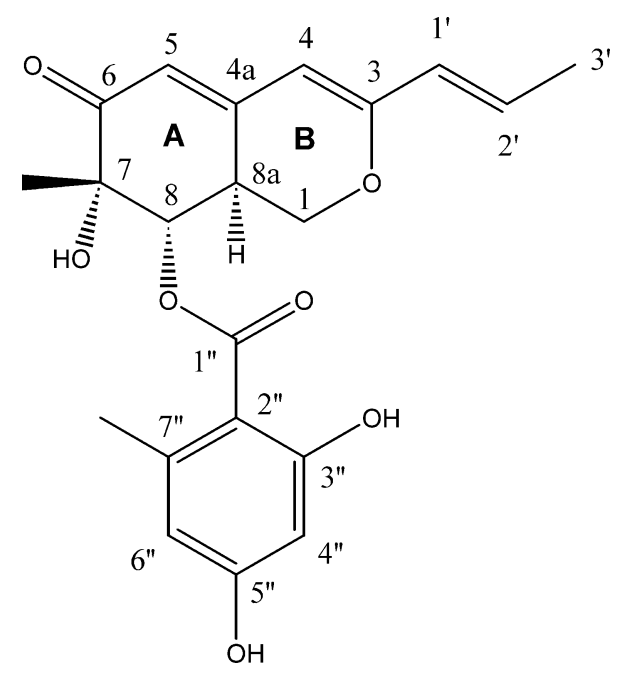

Fig. 1 Structure of Sch 725680 (1)
Present address: V. Gullo: Cetek Corporation, 260 Cedar Hill St. Marlborough, MA 01752, USA

Present address: M. Patel: SMP International LLC, 42 Brentwood Drive, Verona, NJ 07044, USA 
contained proteus peptone ( $5 \mathrm{~g} /$ liter), $\mathrm{NaCl}$ ( $5 \mathrm{~g} /$ liter), $\mathrm{KH}_{2} \mathrm{PO}_{4}(5 \mathrm{~g} /$ liter $)$, yeast extract $(3 \mathrm{~g} /$ liter $)$, cerelose $(20 \mathrm{~g} /$ liter $)$, and soybean grits $(5 \mathrm{~g} /$ liter $)$. The $\mathrm{pH}$ was adjusted to 7.0 prior to autoclaving. Each $250 \mathrm{ml}$ Erlenmeyer flask containing $70 \mathrm{ml}$ of this medium was inoculated with $2 \mathrm{ml}$ of the stock culture. The flasks were incubated at $24^{\circ} \mathrm{C}$ on a rotary shaker at $250 \mathrm{rpm}$ for 96 hours. This seed culture $(2.5 \mathrm{ml})$ was used to inoculate a second stage seed in $250 \mathrm{ml}$ Erlenmeyer flasks, each containing $70 \mathrm{ml}$ of the same seed medium and the flasks were incubated as above for 96 hours.

This second stage seed was then used to inoculate the fermentation medium at $5 \% \mathrm{v} / \mathrm{v}$. The fermentation was carried out in $500 \mathrm{ml}$ Erlenmeyer flasks, each containing $100 \mathrm{ml}$ of the fermentation medium, which consisted of neopeptone $(10 \mathrm{~g} /$ liter $)$ and cerelose $(40 \mathrm{~g} /$ liter $)$. The $\mathrm{pH}$ was adjusted to 7.4 and $\mathrm{CaCO}_{3}(4 \mathrm{~g} /$ liter $)$ was added. The flasks were incubated at $24^{\circ} \mathrm{C}$ on a rotary shaker at $250 \mathrm{rpm}$ for 168 hours.

The harvested fermentation broth (10 liters) was stirred with $2 \mathrm{~kg}$ of $\mathrm{NaCl}$ and 20 liters of acetonitrile (MeCN) for 15 minutes. The organic layer was separated and concentrated to a slurry in vacuo. The slurry material was absorbed onto the polymeric resin, CG161 ( $\sim 200 \mathrm{ml}$, Tosoh Biosep LLC, Montgomeryville, PA, USA) and the salts and hydrophilic substances were removed by washing with 20 liters of water. Then, the absorbed organic material was eluted with $85 \%$ aq. $\mathrm{MeOH}$ (4 liters) to yield $\sim 2.4 \mathrm{~g}$ of dried material after removing solvent in vacuo. Part of this organic material was purified on a semi-preparative ODS-A HPLC column (YMC, $120 \AA$, S-7, 20×250 mm). The column was eluted with a gradient of $\mathrm{MeCN}-\mathrm{H}_{2} \mathrm{O}$ : $5 \sim 100 \% \mathrm{MeCN}$ in 50 minutes, and then held isocratically with $100 \% \mathrm{MeCN}$ for additional 15 minutes with a flow rate of $15 \mathrm{ml} /$ minute. The eluate was collected in $13 \mathrm{ml}$ for each fraction. An enriched complex containing 1 ( $\sim 20 \mathrm{mg})$ was obtained with three injections of $40 \mathrm{mg}$ each of the crude material. The complex was further purified using another HPLC C-18 column (YMC ODS-A, $3 \mu \mathrm{m}$, $4.6 \times 100 \mathrm{~mm}$ ). The column was eluted with a gradient of $\mathrm{MeCN}-\mathrm{H}_{2} \mathrm{O} 5 \sim 50 \%$ in 20 minutes followed by the second gradient of $50 \sim 100 \% \mathrm{MeCN}$ solution in 6 minutes with a flow rate of $0.8 \mathrm{ml} /$ minute and the desired peak containing pure 1 was collected. Combined pure $1(\sim 6 \mathrm{mg})$ was obtained with four injections of $\sim 5 \mathrm{mg}$ each of the enriched material.

The structure of 1 was mainly elucidated by extensive 1D and 2D NMR analyses. In the ${ }^{1} \mathrm{H}-\mathrm{NMR}$ spectrum, a total of 19 carbon-attached protons were counted. Three methyl, one methylene, and two methine signals were observed in the aliphatic region, and six resonances were

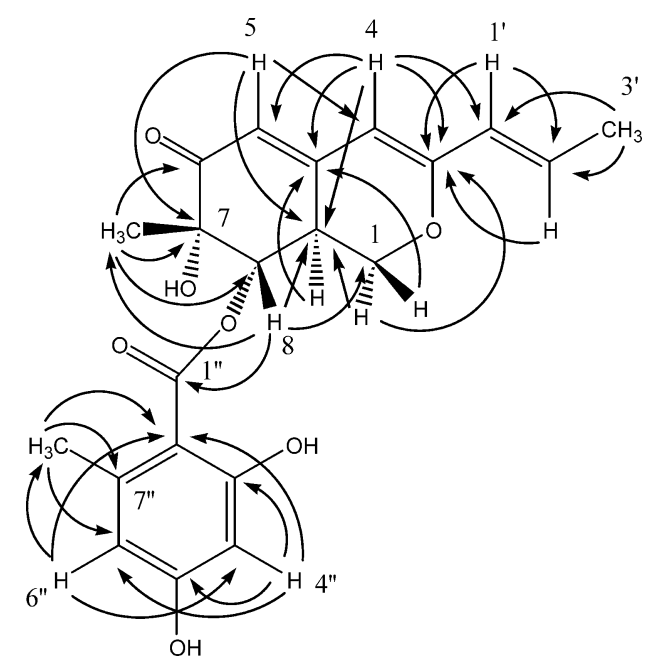

Fig. $2 \mathrm{HMBC}$ correlations of $\mathbf{1}$.

observed in the olefinic/aromatic region. In the ${ }^{13} \mathrm{C}$ NMR spectrum, twenty one carbon signals were detected, in which a conjugated ketone functionality $(\mathrm{C}-6, \delta$ 197.5) was identified. The molecular ion $\mathrm{m} / \mathrm{z} 387,[\mathrm{M}+\mathrm{H}]^{+}$was observed on an ESI MS instrument, and therefore the molecular formula of $\mathbf{1}$ was calculated as $\mathrm{C}_{21} \mathrm{H}_{22} \mathrm{O}_{7}$. Thus three hydroxyl groups were proposed to be present in the molecule. The hydrogenated azaphilone skeleton was mainly determined by ${ }^{1} \mathrm{H}-{ }^{13} \mathrm{C}$ long range correlations measured in an HMBC experiment. The methyl group showing a doublet-doublet resonance $\left(\mathrm{H}_{3}-3^{\prime}, \delta 1.84\right.$, dd, $J=7.0,1.7 \mathrm{~Hz}$ ) in ${ }^{1} \mathrm{H}$ NMR was determined to be adjacent to a double bond consist of two olefinic methine carbons $\left(\mathrm{C}-1^{\prime}\right.$ and $\left.\mathrm{C}-2^{\prime}\right)$ due to the observation of the correlations between $\mathrm{H}_{3}-3^{\prime}$ and $\mathrm{C}-1^{\prime}(\delta 126.7)$ and $\mathrm{C}-2^{\prime}(\delta$ 135.0). This double bond was conjugated to additional two double bonds and further extended to the ketone (C-6) at the other end on the basis of the following correlations: $\mathrm{H}-1^{\prime}$ to $\mathrm{C}-3$; $\mathrm{H}-2^{\prime}$ to C-3; H-4 to C-3, C-4a, C-5, C-8a, and C-1' ; H-5 to C-4, C7 and $\mathrm{C}-8$ a (Fig. 2). The second methyl group $\left(7-\mathrm{CH}_{3}, \delta\right.$ 2.57 , s) substituted on a oxygenated quaternary carbon (C$7)$ was located two bonds away from the conjugated ketone (C-6) and an aliphatic oxygenated methine carbon (C-8, $\delta$ 76.7) due to the significant coupling of $\mathrm{CH}_{3}-7$ and $\mathrm{C}-7, \mathrm{C}-$ 6 , and $\mathrm{C}-8$. An aliphatic methine carbon (C-8a, $\delta$ 36.4) showing long-range correlations to $\mathrm{H}-4, \mathrm{H}-5, \mathrm{H}-8$, and $\mathrm{H}-1$ was determined to be adjacent to C-4a, C-8 and C-1. Therefore, the first six-member ring A was constructed based on these evidences. The oxygenated methylene proton signals $(\mathrm{H}-1 \alpha$ and $\mathrm{H}-1 \beta)$ indicated a three-bond correlation to the olefinic carbon C-3 $(\delta$ 162.2) through an oxygen atom to form the second six-member ring $\mathrm{B}$ identified as a dihydro-pyran moiety. Thus the 6,7,8,8a- 
Table 1 NMR spectral data for compound 1 in $\mathrm{CD}_{3} \mathrm{OD}^{\mathrm{a}}$

\begin{tabular}{|c|c|c|c|}
\hline $\mathrm{C} / \mathrm{H}$ no. & ${ }^{1} \mathrm{H}(\delta)$ & ${ }^{13} \mathrm{C}(\delta)$ & ${ }^{1} \mathrm{H}-{ }^{1} \mathrm{H} \cos Y$ \\
\hline $1 \alpha$ & $4.44,1 \mathrm{H}, \mathrm{dd}, J=10.8,5.2$ & $69.4 \mathrm{t}$ & $\mathrm{H}-1 \beta, \mathrm{H}-8 \mathrm{a}$ \\
\hline $1 \beta$ & $3.83,1 \mathrm{H}, \mathrm{dd}, J=13.6,10.8$ & & $\mathrm{H}-1 \alpha, \mathrm{H}-8 \mathrm{a}$ \\
\hline 3 & & $162.2 \mathrm{~s}$ & \\
\hline 4 & $5.71,1 \mathrm{H}, \mathrm{s}$ & $103.9 \mathrm{~d}$ & \\
\hline $4 a$ & & $153.7 \mathrm{~s}$ & \\
\hline 5 & $5.75,1 \mathrm{H}, \mathrm{d}, J=2.1$ & $117.0 \mathrm{~d}$ & \\
\hline 6 & & $197.5 \mathrm{~s}$ & \\
\hline 7 & & $75.2 \mathrm{~s}$ & \\
\hline 7-Me & $1.30,3 \mathrm{H}, \mathrm{s}$ & $19.9 q$ & \\
\hline 8 & $5.27,1 \mathrm{H}, \mathrm{d}, J=10$ & $76.7 d$ & $\mathrm{H}-8 \mathrm{a}$ \\
\hline $8 a$ & $3.42,1 \mathrm{H}, \mathrm{dddd}, J=13.6,10,5.2,2.1$ & $36.4 d$ & $\mathrm{H}-1 \alpha, \mathrm{H}-1 \beta, \mathrm{H}-8$ \\
\hline $1^{\prime}$ & $5.99,1 \mathrm{H}, \mathrm{dq}, J=15.4,1.7,1.7,1.7$ & $126.7 d$ & $\mathrm{H}-2^{\prime}$ \\
\hline $2^{\prime}$ & $6.45,1 \mathrm{H}, \mathrm{dq}, J=15.4,7.0,7.0,7.0$ & $135.0 \mathrm{~d}$ & $\mathrm{H}-1^{\prime}, \mathrm{H}-3^{\prime}$ \\
\hline $3^{\prime}$ & $1.84,3 \mathrm{H}, \mathrm{dd}, J=7.0,1.7$ & $18.6 q$ & $\mathrm{H}-2^{\prime}$ \\
\hline $1^{\prime \prime}$ & & $172.1 \mathrm{~s}$ & \\
\hline $2^{\prime \prime}$ & & $105.7 \mathrm{~s}$ & \\
\hline $3^{\prime \prime}$ & & $166.2 \mathrm{~s}$ & \\
\hline $4^{\prime \prime}$ & $6.19,1 \mathrm{H}, \mathrm{d}, J=2.5$ & $102.0 \mathrm{~d}$ & $\mathrm{H}-6^{\prime \prime}$ \\
\hline $5^{\prime \prime}$ & & $164.4 \mathrm{~s}$ & \\
\hline $6^{\prime \prime}$ & $6.26,1 \mathrm{H}, \mathrm{d}, J=2.5$ & $112.9 \mathrm{~d}$ & $\mathrm{H}-4^{\prime \prime}$ \\
\hline $7^{\prime \prime}$ & & $145.1 \mathrm{~s}$ & \\
\hline 7"-Me & $2.57,3 \mathrm{H}, \mathrm{s}$ & $24.8 \mathrm{q}$ & \\
\hline
\end{tabular}

${ }^{a}$ Recorded on a Varian Unity $500 \mathrm{NMR}$ instrument at $500 \mathrm{MHz}$ for ${ }^{1} \mathrm{H}$ and $125 \mathrm{MHz}$ for ${ }^{13} \mathrm{C}$, using standard Varian pulse sequence programs (VNMR Version 6.1 Software). $\delta$ in ppm; $J$ in $\mathrm{Hz}$.

tetrahydro- $1 H$-isochromene ring skeleton was determined.

The remaining seven carbons was constructed to represent a 2,4-dihydroxy-6-methyl-benzoyl moiety based on the following observation: correlations $\mathrm{H}-4$ " to C-2", C3", C-5" and C-6"; H-6" to C-2", C-4", C-5", and $\mathrm{CH}_{3}-7^{\prime \prime}$; $\mathrm{CH}_{3}-7^{\prime \prime}$ to $\mathrm{C}-2 "$, C-6", and $\mathrm{C}-7^{\prime \prime}$. The ${ }^{13} \mathrm{C}$ chemical shifts of the highly substituted benzoyl moiety well matched the data of the same benzoyl moiety reported in the literature [15]. The benzoyl group was unambiguously assigned to $8-O$ position based on the correlation from $\mathrm{H}-8$ to $\mathrm{C}-1$ " $(\delta$ 172.1). Thus the two dimensional structure of 1 was determined, and the unambiguous assignment of the ${ }^{1} \mathrm{H}$ and ${ }^{13} \mathrm{C}$ chemical shifts was achieved based on 2D NMR data analyses including ${ }^{1} \mathrm{H}-{ }^{1} \mathrm{H}$ COSY, HSQC, and HMBC as detailed in Table 1.

The stereochemistry of $\mathbf{1}$ was established by analyses of ${ }^{1} \mathrm{H}-{ }^{1} \mathrm{H}$ coupling constants and NOESY. The double bond $\Delta 1^{\prime}, 2^{\prime}$ was determined as trans due to the typical large coupling constant $(J=15.4 \mathrm{~Hz})$. NOE correlation between $\mathrm{H}-1^{\prime}$ and $\mathrm{H}-4$ confirmed the proposed linear conjugation of these double bonds (Fig. 3). The relative stereochemistry on $\mathrm{C}-1, \mathrm{C}-8$, and $\mathrm{C}-8 \mathrm{a}$ was assigned on the basis of the

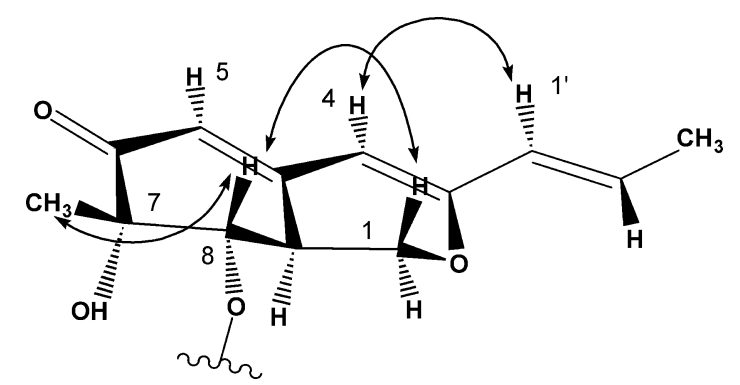

Fig. 3 The relative configuration of $\mathbf{1}$ and NOE correlations observed in NOESY spectrum (represented by double arrows).

NOE correlations between $\mathrm{H}-1 \beta$ and $\mathrm{H}-8$ and between $\mathrm{H}-8$ and $\mathrm{CH}_{3}-7$ as shown in Fig. 3. Thus $\mathrm{H}-8 \mathrm{a}$ was assigned on pseudo-axial position and $\alpha$ orientation, the same as two oxygen atoms (8-O and 7-O). The large coupling constants measured for $\mathrm{H}-8 \mathrm{a}(J=13.6$ and $10 \mathrm{~Hz})$ were consistent with the stereochemistry assignment.

Most of the previously reported azaphilones have benzoyl substitution on $\mathrm{C}-7$ position [1 3]. Benzoyl 
substitution on C-8 for hydrogenated azaphilone is rare [5]. To our best knowledge, Sch725680 (1) represents the second example of a C-8 benzoyl substituted hydrogenated azaphilone.

Sch725680 (1) displayed antifungal activity against Saccharomyces cerevisiae (PM503) [16] and Candida albicans (C43) with MICs of 8 and $64 \mu \mathrm{g} / \mathrm{ml}$, respectively. Compound $\mathbf{1}$ also showed weak antibacterial activity against Staphylococcus aureus at $64 \mu \mathrm{g} / \mathrm{ml}$.

Acknowledgement The authors are grateful to Mr. Lewis B. Fan for extract preparation and Mr. Ross Yang for MS measurement.

\section{References}

1. Itabashi T, Nozawa $\mathrm{K}$, Miyaji $\mathrm{M}$, Udagawa $\mathrm{S}$, Nakajima $\mathrm{S}$, Kawai K. Falconensins A, B, C, and D, new compounds related to azaphilone, from Emericella falconensis. Chem Pharm Bull 40: 3142-3144 (1992)

2. Itabashi $T$, Nozawa K, Nakajima S, Kawai K. A new azaphilone, falconensin $\mathrm{H}$, from Emericella falconensis. Chem Pharm Bull 41: 2040-2041 (1993)

3. Itabashi T, Ogasawara N, Nozawa K, Kawai K. Isolation and structures of new azaphilone derivatives, falconensins $\mathrm{E} \sim \mathrm{G}$, from Emericella falconensis and absolute configurations of falconensins $A \sim$ G. Chem Pharm Bull 44: 2213-2217 (1996)

4. Arai N, Shiomi K, Tomoda H, Tabata N, Tang DJ, Masuma $\mathrm{R}$, Kawakubo T, Ōmura S. Isochromophilones III $\sim \mathrm{VI}$, inhibitors of Acyl-CoA: cholesterol acyltransferase produced by Penicillium multicolor FO-3216. J Antibiot 48: 696-702 (1995) and 48: C2, (1995)

5. Natsume M, Takahashi Y, Marumo S. (-)-Mitorubrinic acid, a morphogenic substance inducing chlamydospore-like cells, and its related new metabolite, $(+)$-mitorubrinic acid $\mathrm{B}$, isolated from Penicillium funiculosum. Agric Biol Chem 49: 2517-2519 (1985)

6. Pairet L, Wrigley SK, Chetland I, Reynolds EE, Hayes MA, Holloway J, Ainsworth AM, Katzer W, Cheng XM, Hupe DJ, Charlton P, Doherty AM. Azaphilones with endothelin receptor binding activity produced by Penicillium sclerotiorum: taxanomy, fermentation, isolation, structure elucidation and biological activity. J Antibiot 48: 913-923 (1995)

7. Tomoda H, Matsushima C, Tabata N, Namatame I, Tanaka H, Bamberger MJ, Arai H, Fukazawa M, Inoue K, Ōmura S. Structure-specific inhibition of cholesteryl ester transfer protein by azaphilones. J Antibiot 52: 160-170 (1999)

8. Toki S, Tanaka T, Uosaki Y, Yoshida M, Suzuki Y, Kita K, Mihara A, Ando Y, Lokker NA, Giese NA, Matsuda Y. RP1551s, a family of azaphilones produced by Penicillium sp., inhibit the binding of PDGF to the extracellular domain of its receptor. J Antibiot 52: 235-244 (1999)

9. Matsuzaki K, Tahara H, Inokoshi J, Tanaka H, Masuma R, Ōmura S. New brominated and halogen-less derivatives and structure-activity relationship of azaphilones inhibiting gp120-CD4 binding. J Antibiot 51: 1004-1011 (1998)

10. Fujimoto H, Matsudo T, Yamaguchi A, Yamazaki M. Two new fungal azaphilones from Talaromyces luteus, with monoamine oxidase inhibitory effect. Heterocycles 30: 607-616 (1990)

11. Nakamura K, Kino T, Niko K, Kyotoo S, Okuhara M. Phospholipase $\mathrm{A}_{2}$ inhibitors containing sclerotiorin from Penicillin sclerotiorum for treatment of inflammatory pancreatitis, and allergy. JP 02255615 A2, Oct. 16, 1990

12. Yasukawa K, Takahashi M, Natori S, Kawai K, Yamazaki M, Takeuchi M, Takido M. Azaphilones inhibit tumor promotion by $12-O$-tetradecanoylphorbol-13-acetate in twostage carcinogenesis in mice. Oncology 51: 108-112 (1994)

13. Yang SW, Chan TM, Terracciano J, Loebenberg D, Patel M, Gullo V, Chu M. A new 5-alkenylresorcinol Sch 725681 from Aspergillus sp. J Antibiot 59: 190-192 (2006)

14. Related references were cited here: Yang SW, Chan TM, Terracciano J, Loebenberg D, Patel M, Chu M. Structure elucidation of Sch 725674 from Aspergillus sp. J Antibiot 58: 535-538 (2005)

15. Quang DN, Hashimoto T, Stadler M, Asakawa Y. Dimeric azaphilones from the xylariaceous ascomycete Hypoxylon rutilum. Tetrahedron 61: 8451-8455 (2005)

16. Yang SW, Chan TM, Pomponi SA, Chen G, Loebenberg D, Wright A, Patel M, Gullo V, Pramanik B, Chu M. Structure elucidation of a new antifungal sterol sulfate, Sch 575867, from a deep-water marine sponge (Family: Astroscleridae). J Antibiot 56: 186-189 (2003) 